\title{
Ископаемые водоросли
}

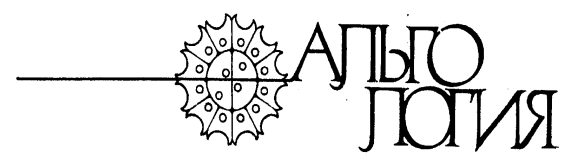

ISSN 0868-854 (Print)

ISSN 2413-5984 (Online). Algologia. 2019, 29(2): 201-216

https://doi.org/10.15407/alg29.02.201

ПУШКАРЬ В.С. ${ }^{1,2}$, ЛИХАЧЕВА О.Ю. ${ }^{1}$, УСОЛЬЦЕВА М.В. ${ }^{3}$

'Дальневосточный геологический институт ДВО РАН, просп. 100 лет Владивостоку, 159, Владивосток 690022, Россия

pushkar@fegi.ru

${ }^{2}$ Владивостокский государственный университет экономики и сервиса,

ул. Гоголя, 41, Владивосток 690014, Россия

vlpushkar@mail.ru

${ }^{3}$ Лимнологический институт СО РАН,

ул. Улан-Баторская, 3, Иркутск 664033, Россия

usmarina@inbox.ru

\section{ЗОНАЛЬНАЯ ДИАТОМОВАЯ ШКАЛА КОНТИНЕНТАЛЬНОГО НЕОГЕНА ПРИМОРЬЯ (ЮГ ДАЛЬНЕГО ВОСТОКА РОССИИ)}

Рассматривается важнейшая проблема стратиграфии и микропалеонтологии разработка высокоразрешающих биостратиграфических шкал, необходимых для построения современной теории биосферной стратиграфии и выделения хронозоны в качестве основной операционной единицы. Именно хронозона должна отражать основные геобиологические события, которые приводили к изменениям состояния палеобиосферы. Разработка и обоснование зональных континентальных шкал, несущих также событийную геобиологическую информацию, серьезно отстают от требований современной стратиграфии. Авторами разработана зональная диатомовая шкала континентального неогена Приморья с использованием новейших данных по таксономии и стратиграфическому распространению диатомей в неогеновых отложениях Приморья с учетом данных изотопного датирования. Анализ стратиграфического распределения диатомей позволил выделить 7 диатомовых зон в интервале нижний миоцен - плиоцен, которые отражают конкретные эволюционные этапы развития диатомовой флоры на Юге Дальнего Востока. Ранний миоцен характеризуется интенсивным развитием представителей родов Aulacoseira, Alveolophora, Ellerbeckia, Pseudoaulacosira и Melosira. На границе раннего и среднего миоцена проявился глобальный климатический оптимум, ставший причиной появления и развития многих родов диатомей и высокого видового разнообразия центрических диатомей на средне-позднемиоценовом этапе развития. Плиоценовый этап ознаменовался появлением родов Stephanodiscus, Cyclotella и Pliocaenicus. Наибольшее вымирание умеренно-тепловодных видов центрических родов на уровне 3,6 млн лет отвечает росту и экспансии ледниковых покровов на обоих полюсах планеты.

Ключе вы е слова : Дальний Восток, диатомеи, неоген, палеоклимат, стратиграфия, тектоника

(C) Пушкарь В.С., Лихачева О.Ю., Усольцева М.В., 2019 


\section{Введение}

Диатомовые одноклеточные водоросли с внешним кремневым скелетом представляют ортостратиграфическую группу, которая широко используется в биостратиграфических построениях благодаря высоким темпам эволюционных изменений и хорошей сохранности в осадках. Поскольку эта группа обладает также высокой чувствительностью к изменениям параметров среды обитания, она используется при палеогеографических реконструкциях.

Целью данной работы является разработка зональной диатомовой шкалы континентального неогена Приморья с учетом новейших данных по таксономии и стратиграфическому распространению диатомей в неогеновых отложениях Приморья, а также данных изотопного датирования.

Решение проблемы зональной стратиграфии континентальных толщ стало первоочередной задачей для развития теории стратиграфии (Мейен, 1989; Гладенков, 1991; Жамойда, 2007). Впервые попытка выделения диатомовых зон была предпринята при изучении неогеновых толщ Приморья. В миоцен-плиоценовом интервале было выделено три диатомовых зоны (Пушкарь, Короткий, 1985). На основе полученных данных и данных эволюционного развития диатомей в неогене Приморья предложен вариант диатомовой зональной шкалы (Моисеева, 1995), которая соответствует унифицированной схеме неогеновых и плиоценовых отложений Приморья (Решения..., 1994). Однако практика геологического картирования и дальнейшие диатомовые исследования выявили ряд недочетов при разработке зональной шкалы, а также в действующей парадигме унифицированной региональной схемы кайнозойских отложений Приморья. Выделены новые стратиграфические подразделения, получены данные абсолютного датирования, позволившие пересмотреть возраст ряда неогеновых свит и горизонтов (Павлюткин и др., 2004; Павлюткин, Чекрыжов, 2007; Павлюткин, Петренко, 2010). Пересмотрена возрастная последовательность диатомовых зон А.И. Моисеевой. Оказалось, что диатомовые зоны отражают не столько эволюционную последовательность в развитии диатомей, сколько разновозрастные смены фациальных обстановок в условиях изменения параметров среды (Моисеева, 1995).

Ряд таксономических преобразований в систематике диатомовых водорослей, описание новых таксонов диатомей в неогеновых толщах Приморья (Dubrovina et al., 2014; Usoltseva et al., 2018), уточнение стратиграфического распространения диатомей позволили внести изменения и в более поздний вариант биостратиграфической схемы (Лихачева и др., 2009). Установлены уровни именно эволюционного появления и исчезновения зональных маркеров по отсутствию их рекуррентной встречаемости в ниже- и вышележащих толщах, формировавшихся в аналогичных фациальных условиях, а также при их корреляции со стратиграфическим распространением в континен- 
тальных неогеновых толщах Байкала и Калифорнии (Krebs et al., 1987; Khursevich, 2006). Кроме того, границы зон несут также событийный характер (изменения климата, фациальных обстановок, этапы тектогенеза) на основе определения референтных признаков зон (Пушкарь, 2012). По сути, авторами предложена новая зональная диатомовая шкала.

\section{Материалы и методы}

Материалом для диатомового анализа послужили полевые многолетние исследования неогеновых толщ Приморья. Изучено более 30 разрезов, имеющих палеоботаническую и радиометрическую характеристики (Павлюткин и др., 1993, 2004; Павлюткин, Петренко, 2010). Основное внимание при изучении комплексов диатомей в неогеновых отложениях уделено стратотипам и опорным разрезам горизонтов и свит (рис. 1).

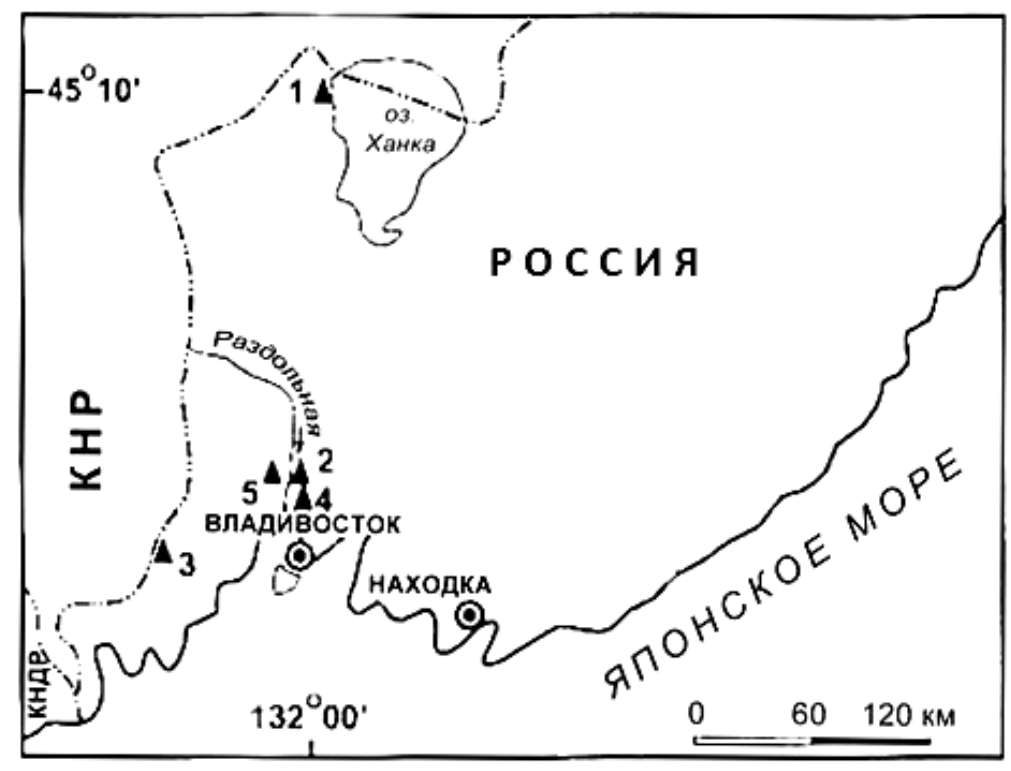

Рис. 1. Расположение групп разрезов неогеновых отложений в южной части Приморья: 1 - голостратотип новокачалинской свиты (средний миоцен); 2 гипостратотип усть-суйфунской свиты (верхний миоцен); 3 - гипостратотип синеутесовской свиты (нижняя часть нижнего миоцена); 4 - опорные разрезы шуфанского горизонта (плиоцен); 5 - опорные разрезы нежинской свиты (верхняя часть нижнего миоцена)

Результаты биостратиграфических исследований, как правило, используются при разработке местных и региональных схем и шкал. Региональная шкала, построенная на материале местных схем, служит основой для разработки легенд среднемасштабных геологических карт, при палеогеографических и палеогеодинамических реконструкциях (Жамойда, 2007). Она имеет особое значение при корреляции разно- 
фациальных отложений, особенно континентальных. Поэтому одним из основополагающих принципов стратиграфии, лежащим в основе биостратиграфических корреляций, является принцип гомотаксальности, обеспечивающий смыкаемость возрастных разнофациальных комплексов, в т. ч. диатомовых, даже при отсутствии зональных видовиндексов зон (Жамойда, 2007).

Как известно, С.В. Мейен (1989) обосновал признание принципа гомотаксальности в качестве третьего фундаментального принципа стратиграфии, назвав его принципом Гексли. Под гомотаксисом Т. Гексли понимал идентичную (однопорядковую) последовательность ископаемых комплексов фауны или флоры в разрезах, которые в данном случае являются гомотаксальными. Он предложил применять понятие гомотаксальности при корреляции разрезов не только по палеонтологическим, но и по другим признакам или отражаемым ими событиям, например, опираясь на палеоклиматические реконструкции, смену фациальных обстановок или на одинаковую упорядоченность палеоэкосистем (Мейен, 1989). На основе этого принципа учитывается возможность неодновременного существования идентичных или близких фаун (флор) в различных участках планеты или региона. В то же время устанавливается синхронность отложений при получении доказательств стратиграфического значения какого-либо признака (например, палеоклиматического или конкретного этапа тектогенеза), наблюдаемого в разрезе. Этот принцип играет важную роль при разработке экостратиграфических (событийных) шкал (Пушкарь, 2012). Но фациальная пестрота континентальных отложений влечет за собой соответствующее разнообразие диатомовых комплексов. В такой ситуации установить гомотаксальность при биостратиграфической корреляции лишь по смене таксономического состава комплексов диатомей практически невозможно. Поэтому при определении гомотаксальных последовательностей в разнофациальных разрезах, согласно дополнениям С.В. Мейена, важно выяснить причинноследственные отношения между палеоклиматической ритмикой, фациальным режимом и изменениями экологических структур диатомовых комплексов.

Основные процедуры при выделении биостратиграфических комплексов, отражающих эволюционные этапы развития диатомовой флоры, и выборе видов-индексов конкретных зон сводятся к такой последовательности (Пушкарь, 2012; Пушкарь и др., 2014): анализ стратиграфического взаимоотношения изученных разрезов в полевых условиях с использованием принципа Стено; выделение референтных слоев с диатомовой флорой для привязки первичной возрастной и генетической стратиграфической информации, их латеральное прослеживание в различных континентальных фациях; объединение одновозрастных разнофациальных слоев в зоны и анализ изменчивости экологических структур комплексов, обеспечивающий соблюдение принципа Гексли по климатическому фактору. Зона должна отражать 
эволюционный этап в развитии диатомовой флоры, а eе возраст подтверждаться данными по абсолютному датированию. При этом видиндекс зоны должен, по возможности, отвечать условию его нахождения в речных и озерных фациях. Фациальная пестрота, прослеживающаяся в одном и том же стратиграфическом пространстве, обязательно требует определения характера исчезновения таксона (экологическое или эволюционное) из референтного слоя, поэтому границы зон должны иметь не только эволюционную диатомовую характеристику, но и абиотическую событийную (климат, тектогенез и др.).

\section{Результаты и обсуждение}

По сравнению с морскими диатомеями континентальные обладают гораздо более высокой скоростью видообразования в силу пестроты наземных биотопов и изменчивости экологических параметров. Они также более чувствительны к колебаниям среды обитания, что приводит к широким спектрам фенотипической изменчивости. Все это, с одной стороны, делает их хорошим инструментом при восстановлении параметров палеосред, а с другой - затрудняет корреляцию фациально разнородных толщ, поскольку они содержат диатомовые комплексы с несопоставимыми таксономическими и экологическими структурами. Поэтому выделение референтных слоев, охватывающих одновозрастные генетически различные фации и обладающих уникальными признаками, очень важно при разработке зональной стратиграфии. Референтными признаками могут быть палеоклиматическая ритмика и различия между эволюционными этапами развития диатомей, комплексы которых представляют гомотаксальную последовательность, лежащую в основе корреляции разрезов и установлении соответствующих зон с характеристикой их стратиграфических границ. Именно поэтому предлагаемая шкала является оригинальной и обоснованной (рис. 2).

При выборе референтных признаков зон предпочтение отдано родам Alveolophora Moisseeva et Nevretdinova, Pseudoaulacosira Lupikina \& Khursevich, Tetracyclus Ralfs, Cyclotella (Kützing) Brébisson) и Aulacoseira Thwaites (формы «prae» и кольцевые колонии), которые хорошо прослеживаются как в озерных, так и речных фациях. Хорошими дополнительными эволюционными маркерами являются роды Actinocyclus Ehrenberg, Mesodictyon Theriot et Bradbury, Pliocaenicus Round et Håkansson, Stephanodiscus Ehrenberg, но они встречаются в аллювиальных фациях гораздо реже. Немаловажное значение играет морфологическая изменчивость признаков, особенно характер и конфигурация соединительных шипов и форма колоний у рода Aulacoseira Thwaites, что в дальнейшем может послужить базой для выделения инфразональных подразделений на уровне фенозон. Наиболее характерные и зональные виды диатомей представлены в Таблице. 


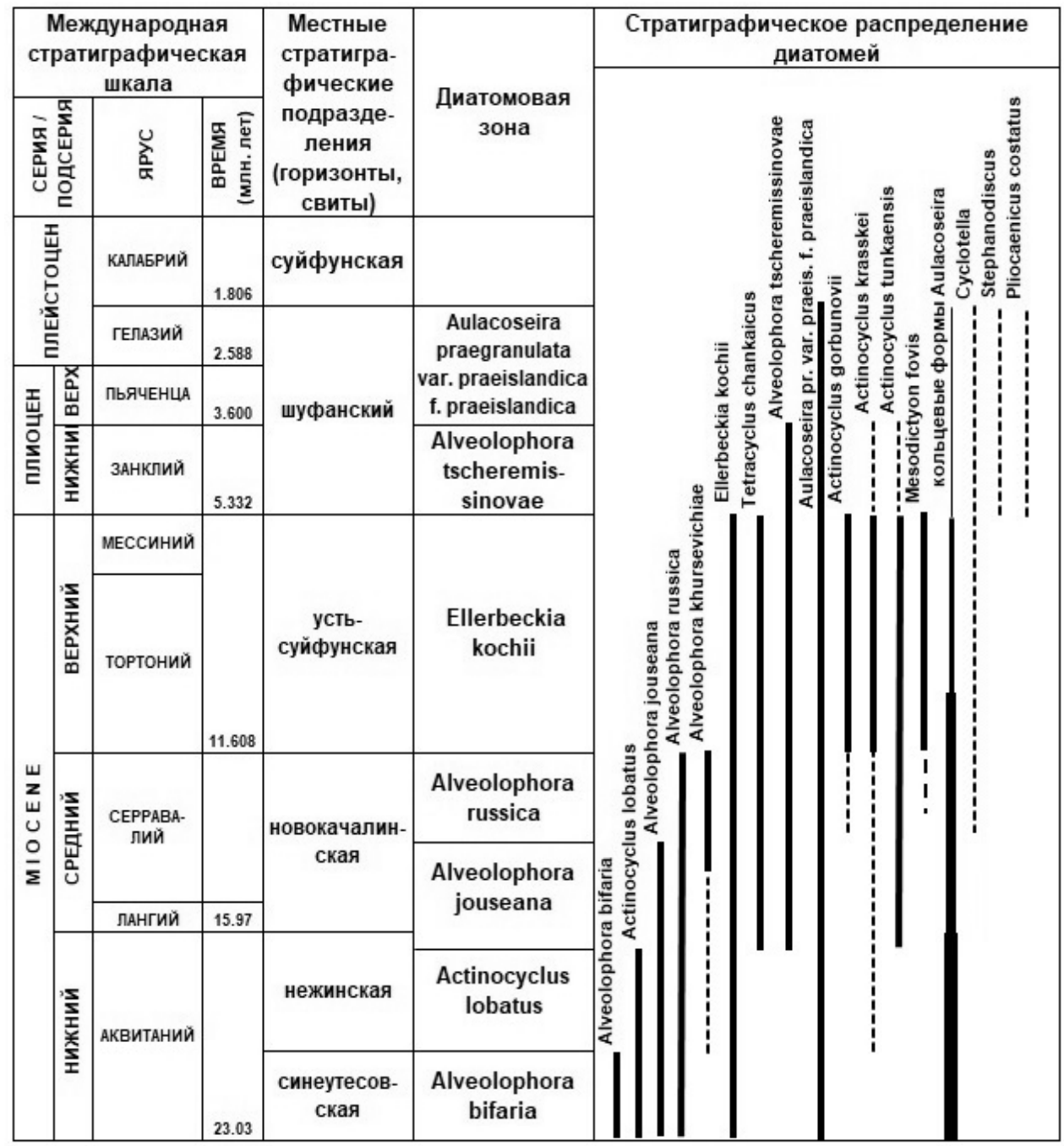

Рис. 2. Стратиграфическое распространение диатомей и зональная диатомовая шкала неогеновых отложений Приморья. Местные стратиграфические подразделения указаны в соответствии с Унифицированной региональной шкалой неогена (Решения..., 1994; Павлюткин, Петренко, 2010)

Зона Alveolophora bifaria (голостратотип синеутесовской свиты, нижняя часть нижнего миоцена). Верхняя граница определяется по вымиранию вида-индекса и первому появлению видов Actinocyclus krasskei f. krasskei Bradbury et Krebs и Alveolophora khursevichiae Usoltseva, Pushkar et Likhacheva. Нижняя граница не установлена. Достоверным признаком этой зоны является высокая встречаемость Actinella brasiliensis Grunow и кольцевых колоний Aulacoseira (референтный признак). 


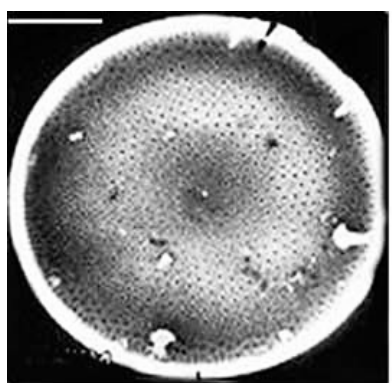

1

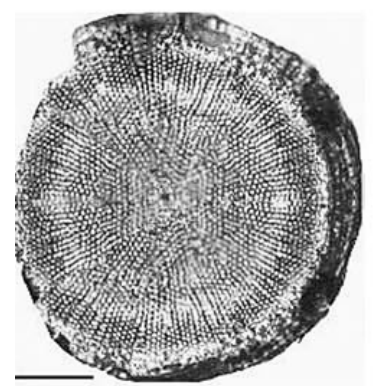

4

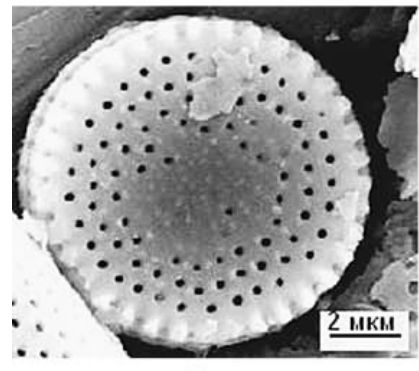

7

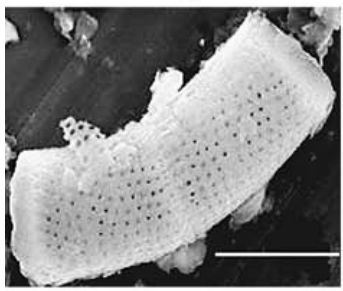

10

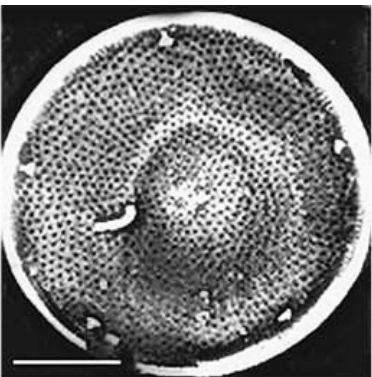

2

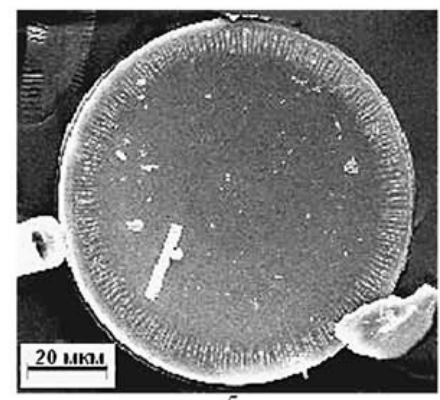

5

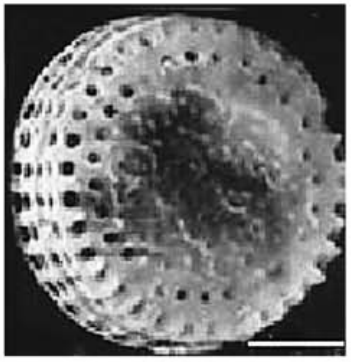

8

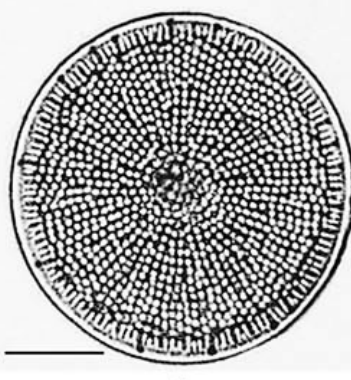

3
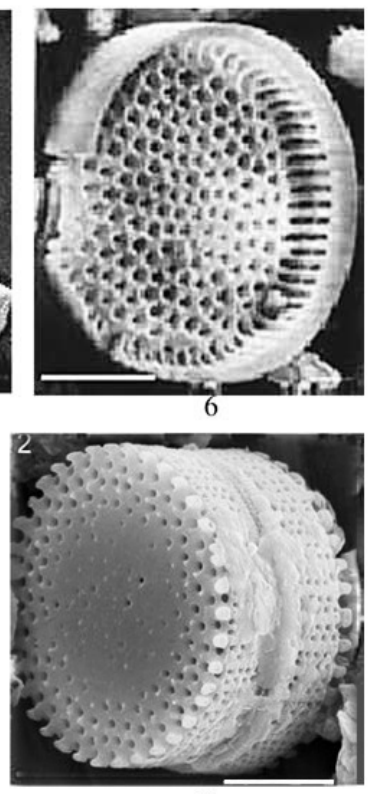

9

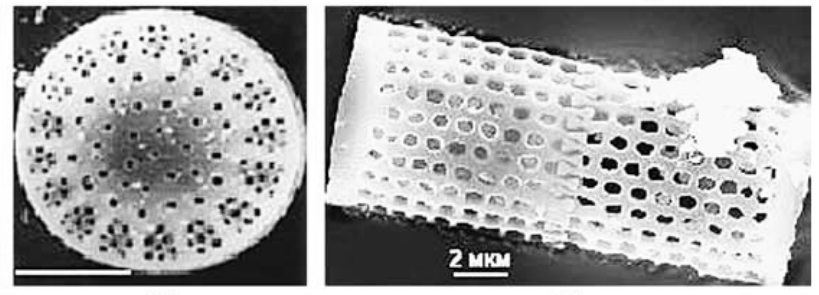

11

12

Таблица. Зональные виды диатомей: 1 - Actinocyclus gorbunovii var. gorbunovii Bradbury et Krebs; 2 - Actinocyclus krasskei f. krasskei Bradbury et Krebs; 3 - Mesodictyon fovis Theriot, Bradbury et Krebs; 4 - Actinocyclus lobatus (Rubina) Rubina et Khursevich; 5 Ellerbeckia kochii (Pantocsek) Moisseeva; 6- Alveolophora bifaria (Moisseeva \& Nevretdinova) Khursevich; 7 - Alveolophora tscheremissinovae (Khursevich) Khursevich; 8 - A. jouseana (Moisseeva) Moisseeva; $9-$ A. khursevichiae Usoltseva, Pushkar et Likhacheva; 10 - Aulacoseira praegranulata var. praegranulata f. curvata (Jousé) Moisseeva; 11 - Alveolophora russica Usoltseva, Kociolek \& Khursevich; 12 - Aulacoseira praegranulata var. praegranulata f. praegranulata (Jousé) Moisseeva (1, 2, 6- фото Г.К. Хурсевич). Линейка без цифр: 10 мкм 
Характерный комплекс диатомей, отражающий эволюционный этап в развитии диатомей начала раннего миоцена, представлен Aulacoseira praegranulata (Jousé) Simonsen var. praegranulata f. praegranulata $+\mathrm{f}$. curvata, A. praegranulata var. praeislandica (Jousé) Moisseeva + f. curvata (Jousé) Moisseeva, A. elliptica Usoltseva et Tsoy, Alveolophora russica Usoltseva, Kociolek et Khursevich, A. jouseana (Moisseeva) Moisseeva, A. bifaria (Moisseeva et Nevretdinova), Ellerbeckia arenaria f. teres (Brun) Crawford, E. kochii (Pantocsek) Moisseeva, Actinocyclus lobatus (Rubina) Rubina et Khursevich, Actinella brasiliensis Grunow, Desmogonium guianense Ehrenberg f. antiqua Lupik. Подобный комплекс обнаружен в пресноводных нижнемиоценовых отложениях плато Уллын Японского моря (Цой, Усольцева, 2016).

Комплекс диатомей зоны свидетельствует о теплом климате на юге Дальнего Востока, что подтверждается палеоботаническими данными (Павлюткин, Петренко, 2010), и активизации Восточно-Азиатского муссона. По-видимому, причиной таких климатических изменений в раннем миоцене было усиление тектонической активности окраины Евразийского континента, выразившееся в поднятии Тибетского плато. Это привело к перераспределению атмосферных потоков и усилению термической контрастности между материком и океаном. Формирующийся в это время Восточно-Азиатский атмосферный барический максимум и стал существенным региональным климатическим фактором, оказавшим огромное воздействие на различные компоненты природной среды умеренных широт Восточной Азии в кайнозое (Wang et al., 2003). Вторым важным фактором, определившим региональный климат, стало начало раскрытия Японского моря и дрейф Японии к востоку (Павлюткин, Голозубов, 2010; Iijuma et al., 1990). Нижняя часть зоны датирована 25,3 верхняя - 20,9 млн лет (Павлюткин и др., 1993).

Зона Actinocyclus lobatus (нежинская свита, верхняя часть нижнего миоцена). Нижняя граница проведена по эволюционному исчезновению Alveolophora bifaria и первому появлению Alveolophora khursevichiae и Actinocyclus krasskei f. krasskei. Верхняя граница проводится по вымиранию вида-индекса и первому эволюционному появлению Actinocyclus tunkaensis Khursevich, Alveolophora tscheremissinovae (Khursevich) Khursevich, Tetracyclus chankaicus Dubrovina, Usoltseva, Pushkar \& Likhacheva. Характерный комплекс диатомей представлен Aulacoseira praegranulata var. praegranulata f. praegranulata et f. curvata (Jousé) Moisseeva, A. praegranulata var. praeislandica et f. curvata, A. italica (Kützing) Simonsen, Alveolophora russica, A. jouseana, Ellerbeckia arenaria $\mathrm{f}$. teres, E. kochii, Melosira undulata (Ehrenberg) Kützing, Actinocyclus lobatus, A. krasskei f. krasskei. Среди бентических видов высока частота встречаемости представителей рода Tetracyclus. В экологической структуре комплексов зоны отмечается тенденция к усилению потепления климата. В это время происходит расширение акватории Японского моря и формирование термического контраста между западной и 
восточной поверхностными водными массам (Павлюткин, Голозубов, 2010). Началось синергетическое влияние окраинных морей СевероЗападной Пацифики и муссонной активности на региональный климат, что привело к формированию достаточно широкой системы озерных водоемов и началу формирования диатомитовых толщ (Лихачева, 2009). Зона датирована 22,87; 20,2 (основание); 20,1; 19,7; 18,8; 18,1 (кровля) млн лет (Павлюткин и др., 1993).

Зона Alveolophora jouseana (нижняя часть голостратотипа новокачалинской свиты, самая верхняя часть нижнего миоцена - нижняя часть среднего миоцена). Нижняя граница определяется признаками верхней границы зоны Actinocyclus lobatus, а также эволюционным исчезновением ряда овальных Aulacoseira, характерных для раннего миоцена (Цой, Усольцева, 2016). Верхняя граница определяется по вымиранию вида-индекса Alveolophora jouseana и появлению вида Actinocyclus gorbunovii Bradbury et Krebs. Комплекс диатомей зоны характеризуется относительно высоким родовым (42) и видовым (98) богатством при низкой степени их доминирования. В основном это сублиторальные тихопелагические и планктонные виды родов Aulacoseira: A. praegranulata var. praegranulata + var.praeangustissima (Jousé) Moisseeva, а также A. praegranulata var. praeislandica (Jousé) Moisseeva, A. distans (Ehrenbegr) Simonsen, A. italica (Kützing) Simonsen f. italica. Немаловажное значение в комплексе имеют Alveolophora russica, A. jouseana, Ellerbeckia kochii, E. arenaria (Moore ex Ralfs) Crawford var. teres (Brun) Crawford, Actinocyclus gorbunovii + A. gorbunovii var. fossa Bradbury et Krebs, A. krasskei (Krasske) Bradbury et Krebs + f. krasskei, Actinella brasiliensis и Melosira undulata с широкой морфологической изменчивостью.

До $13 \%$ состава флоры принадлежит представителям родов Tetracyclus Ralfs, Eunotia Ehrenberg, Achnanthes Bory, Navicula Bory, Pinnularia Ehrenberg, Cymbella Agardh - бентическим и реофильным видам. В целом экологическая структура комплекса свидетельствует о сублиторальном генезисе его формирования в достаточно прогреваемом (тепловодных видов до 42\%) озерном водоеме при усиливающемся влиянии речного стока (референтный признак). «Теплый» характер комплекса отражает главный климатический оптимум на границе раннего и среднего миоцена (референтный признак) - Monterey carbon excursion (Wang et al., 2003).

Низкое доминирование диатомей и достаточно высокое их видовое разнообразие (128 видов, принадлежащих к 39 родам) - признак быстропериодических изменений условий окружающей среды с тенденцией к ярко выраженному потеплению. Это обстоятельство обеспечило высокую биопродуктивность диатомей $\left(21,11 \cdot 10^{7}\right.$ створок · $\mathrm{cm}^{-2} \cdot$ тысяча лет $\left.{ }^{-1}\right)$, что привело к формированию диатомитовых толщ (референтный признак) мощностью до 10-15 м. В тектогенезе окраины континента в начале среднего миоцена завершается спрединг Японского и Южно-Китайского морей. По-видимому, процесс формирования 
окраинных морей Западной части Тихого океана был единым (Wang et al., 2003). Начинается усиление контраста между летним и зимним муссонами, влиявшего на региональный климат. Однако ослабленный зимний муссон при интенсивном летнем не стал экологическим барьером для развития субтропических диатомей. Для комплекса получена серия датировок в интервале 18,1-14,9 млн лет (Павлюткин и др., 1993, 2004).

Зона Alveolophora russica (верхняя часть голостратотипа новокачалинской свиты, верхняя часть среднего миоцена). Верхняя граница зоны определяется по вымиранию вида-индекса и Alveolophora khursevichiae. Комплекс диатомей насчитывает 68 видов, принадлежащих к 34 родам, характеризуется сменой сублиторальной структуры на пелагическую роль планктонных видов возрастает в основном за счет Aulacoseira praegranulata (до 58,5\%, но при полном отсутствии форм curvata). Значительная доля в комплексе принадлежит Melosira undulata (13\%). Чаще встречается Alveolophora russica (до 15,6\%). Отмечаются более низкое видовое разнообразие по отношению к нижележащему комплексу, нечеткая морфологическая изменчивость полиморфных видов родов Aulacoseira, Melosira и Tetracyclus, а также выраженное доминирование $A$. praegranulata $(58,5 \%)$, что свидетельствует о более постоянных условиях среды обитания диатомей. Значительная доля планктонных видов (до 78,7\%) свидетельствует об увеличении площади озерных водоемов и их глубины. Группа бентоса представлена Tetracyclus lacustris Ralfs, T. ellipticus var. lancea f. lata Ehrenberg и Tabellaria fragilarioides Lupikina (в сумме до 14\%). В эволюционном плане отмечается развитие видов родов Cyclotella и Stephanodiscus, что является характерной особенностью соответствующего этапа развития диатомовой флоры. Учитывая то, что первые представители рода Cyclotella появляются во второй половине среднего миоцена (Krebs et al., 1987; Khursevich, 2006), комплекс диатомей зоны Alveolophora russica следует датировать второй половиной среднего миоцена. Кроме того, в данном комплексе происходит замещение $A$. jouseana на A. russica. Здесь в обилии представлена A. khursevichiae, что позволяет ее считать важнейшим маркером зоны и верхней границы серравалия (референтный признак). Отмечено почти полное (за редким исключением) отсутствие родов Actinocyclus и Mesodictyon при доминировании видов рода Aulacoseira. Для зоны характерен также высокий полиморфизм видов родов Melosira, Aulacoseira, особенно Tetracyclus (референтный признак). Комплекс зоны, отражая конкретный эволюционный этап в развитии диатомей, содержит 28$35 \%$ вымерших таксонов. Биопродуктивность диатомей заметно снижается, составляя $14,98 \cdot 10^{7}$ створок $\cdot \mathrm{cm}^{-2} \cdot$ тысяча лет $^{-1}$, что свидетельствует о похолодании климата при отсутствии резких колебаний. Для этого времени, видимо, характерно усиление контраста между летним и зимним муссонами за счет активизации зимнего, что подтверждается находками листовой флоры (Павлюткин и др., 2004). 
Отчетливое проявление сибирского антициклона было синергетически связано с глобальным похолоданием на планете (Wang et al., 2003). На территории Приморья продолжает существовать обширная сеть озерных водоемов с накоплением диатомитов. Возраст зоны 14,9-11,8 млн лет (Павлюткин и др., 1993, 2004).

Зона Ellerbeckia kochii (гипостратотип усть-суйфунской свиты, верхний миоцен). Возраст 11,8-5,3 млн лет. На нижней границе исчезают Alveolophora russica и A. khursevichiae. На верхней границе исчезают вид-индекс, а также Tetracyclus chankaicus Dubrovina, Usoltseva, Pushkar \& Likhacheva, Actinocyclus gorbunovii и Mesodictyon fovis. Появляются виды родов Stephanodiscus и Pliocaenicus. Характерный комплекс представлен Aulacoseira praegranulata var. praeislandica, A. praegranulata var. praegranulata f. praegranulata, A. italica, A. italica var. valida (Grunow) Simonsen, Ellerbeckia kochii, Mesodictyon fovis, Tetracyclus lacustris Ralf, T. ellipticus var. lancea (Ehrenberg) Hust., Fragilariopsis bicapitata var. lineolata (Moisseeva), Fragilariopsis nitzschioides var. kamtschatica Lupik., F. miocenica var. tetranoides Moisseeva, Eunotia majuscula Moisseeva, E. nikolskiae Moisseeva, Gomphonema miocenica Moisseeva. Структура комплекса диатомей свидетельствует о холодном климате при усилении зимнего муссона. На этот период приходятся два глобальных похолодания - мессинский кризис (Wang et al., 2003). Значительное увеличение в экологических структурах комплексов диатомей бентических, особенно реофильных диатомей родов Fragilaria Lyngbye, Fragilariforma Williams et Round, Staurosira Ehrenberg, Achnanthes Bory, Planothidium F.E.Round et L.Bukhtiyarova и Tetracyclus Ralfs (в сумме до 45\%) - свидетельство завершения тектогенеза Сихотэ-Алиня и формирования рек высоких порядков, что отразилось на замещении в пределах Приморья озерных фаций озерно-алювиальными и аллювиальными (референтный признак). Комплекс датирован 8,6; 8,8; 10,7; 10,8; 11,8 млн лет (перс. сообщение Сатоси Окамура - Satoshi Okamura Хоккайдский университет, Япония).

Зона Alveolophora tscheremissinovae (нижний плиоцен, шуфанский горизонт). Верхняя граница зоны проводится по вымиранию видаиндекса. Возраст 5,3-3,6 млн лет. Комплекс диатомей характеризуется Alveolophora tscheremissinovae, Aulacoseira praegranulata var. praeislandica, Melosira undulata, Ellerbeckia arenaria f. teres, Fragilariforma bicapitata (A.Mayer) D.M.Williams et Round, Cymbella tumida (Bréb.) Van Heurck, Sellaphora americana (Ehrenberg) D.G.Mann и Cymbella australica (A.S.) Cl. Вымерших видов всего около 10\% (референтный признак). Наблюдается более высокое видовое разнообразие, чем в предыдущем комплексе, а также незначительное участие теплолюбивых видов (10-15\%), что соответствует небольшому потеплению климата начала плиоцена.

Зона Aulacoseira praegranulata var. praeislandica (шуфанский горизонт, верхний плиоцен). Верхняя граница соответствует уровню вымирания вида-индекса. Возраст 3,6-1,92 млн лет. Возрастной комплекс, отражающий эволюционный этап развития диатомей, представлен 
Aulacoseira praegranulata var. praeislandica, A. distans, A. praegranulata var. praegranulata, A. italica, Melosira undulata, Ellerbeckia arenaria f. teres, Eunotia clevei Grunow (= Amphorotia clevei (Grunow) Williams et Reid), Tetracyclus ellipticus var. lancea, Tetracyclus ellipticus var. lancea. Вымерших видов, кроме грубопанцирных разновидностей $A$. praegranulata, нет. Комплекс отражает новую волну похолодания и стабилизацию холодных условий. Доминирующее положение в муссонной циркуляции занимает зимний муссон. С этого момента начинается сосуществование и экспансия полярных ледниковых шапок (переход планеты из режима Green house в режим Ice house), определивших формирование современной климатической системы Земли (Wang et al., 2003).

\section{Заключение}

Анализ стратиграфического распределения диатомей позволил авторам выделить 7 диатомовых зон в интервале нижний миоцен - плиоцен, отражающих конкретные эволюционные этапы развития диатомовой флоры на Юге Дальнего Востока России. Они обусловлены глобальными климатическими изменениями и региональным ВосточноАзиатский муссоном, связанным с гималайским тектогенезом. Смена фациальных обстановок седиментогенеза в Приморье от озерных к аллювиальным обусловлена формированием высокопорядковой речной сети в результате завершения формирования горной системы СихотэАлинь в позднем миоцене. Это повлияло на развитие приморской неогеновой флоры диатомей, характеризующейся высоким эндемизмом. Роды Mesodictyopsis и Tertiariopsis, столь обильно встречающиеся в осадках Байкала и Тункинской котловины, не получили своего развития в пресноводных неогеновых водоемах Приморья.

Раннемиоценовый этап характеризуется интенсивным развитием родов Aulacoseira, Alveolophora, Ellerbeckia, Pseudoaulacosira и Melosira. Отмечается обилие кольцевых колоний рода Aulacoseira. Среднепозднемиоценовый этап соответствует наибольшему видовому разнообразию пресноводных центрических диатомей (15 родов, до 65 видов). В общем составе диатомовой флоры насчитывается до $35 \%$ вымерших видов и разновидностей. Плиоценовый этап ознаменовался появлением и развитием видов родов Stephanodiscus, Cyclotella и Pliocaenicus. Такая же этапность характерна для неогенового времени байкальского региона, однако степень доминирования тех или иных таксонов различна, что свидетельствует об эндемичности флоры Байкала и Приморья.

В конце раннего миоцена и начале среднего проявился глобальный климатический оптимум, хотя на юге Дальнего Востока он был сглажен вследствие интенсификации Восточно-Азиатского муссона и возникновения систем теплых и холодных течений в Японском море. Именно этот рубеж ознаменовался развитием многих центрических диатомей и их высокой биопродуктивностью, что ставит его в ранг реперных уровней. Для этого времени характерны рост видового 
разнообразия и появление многих таксонов. Наибольшее вымирание умеренно-тепловодных видов центрических родов на уровне 3,6 млн лет отвечает росту и экспансии ледниковых покровов на обоих полюсах планеты.

Авторы выражают глубокую благодарность Г.К. Хурсевич (БГПУ им. М. Танка, Минск, Беларусь) за помощь в проведении диатомового анализа и идентификацию видов диатомей.

\section{СПИСОК ЛИТЕРАТУРЫ}

Гладенков Ю.Б. 1991. Современные проблемы зональной стратиграфии. Изв. АН СССР. Сер. геол. 10: 3-8.

Жамойда А.И. 2007. Биостратиграфическая корреляция, биостратиграфические шкалы и схемы. В кн.: Вопросы стратиграфии, палеонтологии и палеогеографии. СПб.: Изд-во СПбГУ. С. 43-56.

Лихачева О.Ю., Пушкарь В.С., Черепанова М.В., Павлюткин Б.И. 2009. Зональная диатомовая шкала и основные геобиологические события неогена Приморья. Вестн. ДВО РАН. 4: 64-72.

Мейен С.В. 1989. Введение в теорию стратиграфии. М.: Наука. 216 с.

Моисеева А.И. 1995. Расчленение континентальных отложений неогена Дальнего Востока по диатомеям. Стратиграфия. Геол. корреляция. 3(5): 92-103.

Павлюткин Б.И., Голозубов В.В. 2010. Палеоботанические свидетельства времени возникновения Японского моря. Вестн. КРАУНЦ. Науки о Земле. 2(16): 19-26.

Павлюткин Б.И., Петренко Т.И. 2010. Стратиграфия палеоген-неогеновых отложений Приморья. Владивосток: Дальнаука. 164 с.

Павлюткин Б.И., Чекрыжов И.Ю. 2007. К проблеме корреляции дальневосточных миоценовых флор эпохи климатического оптимума. Докл. Академии наук. 416(5): $662-665$.

Павлюткин Б.И., Ганзей С.С., Пушкарь В.С., Петренко Т.И. 1993. Палеоботаническая характеристика и радиометрическое датирование неогеновых отложений южного Приморья. Стратиграфия. Геол. корреляция. 1(6): 40-47.

Павлюткин Б.И., Пушкарь В.С., Черепанова М.В., Петренко Т.И. 2004. Проблемы стратиграфии миоцена Приханкайской впадины (Дальний Восток России). Тихоокеан. геология. 23(4): 73-85.

Пушкарь В.С. 2012. Основные проблемы диатомового анализа и возможные пути их решения. В кн.: Современная палеонтология: Труды XV Bсерос. микропалеонтол. совещ. (Геленджик, 12-16 сент. 2012 г.). Москва. С. 362-365.

Пушкарь В.С., Короткий А.М. 1985. Зональная стратиграфия континентального верхнего кайнозоя Сихотэ-Алиня. 2012. В кн.: Стратиграфия кайнозоя Дальнего Востока. Владивосток. С. 22-23.

Пушкарь В.С., Черепанова М.В., Лихачева О.Ю. 2014. Зональная диатомовая шкала плиоцена и квартера Северной Пацифики. Альгология. 24(1): 94-117. https://doi.org/10.15407/alg24.01.094 
Решения 4-го Межведомственного стратиграфического совещания по докембрию и фанерозою юга Дальнего Востока и Восточного Забайкалья. 1994. Хабаровск: ХГГГП. $124 \mathrm{c}$.

Цой И.Б., Усольцева М.В. 2016. Миоценовые пресноводные диатомеи из отложений восточного склона подводного плато Уллын (возвышенность Криштофовича) Японского моря. Стратиграфия. Геолог. корреляция. 24(3): 62-80. https://doi.org/10.7868/S0869592X16020071

Dubrovina Yu., Usoltseva M., Pushkar V., Likhacheva O. 2014. Tetracyclus chankaicus, a new species from Miocene sediments of the Khanka Lake, Primorye, Russia. Diatom Res. 29(2): 111-118. https://doi.org/10.1080/0269249X.2013.833137

Iijuma A., Tada R. 1990. Evolution of Tertiary sedimentary basins of Japan in reference to opening of the Japan Sea. J. Fac. Sci. Hokkaido Univ. Ser. 2. 22(2): 121-171.

Khursevich G. 2006. Evolution of the extinct genera belonged to the family Stephanodiscaceae (Bacillariophyta) during the last eight million years in Lake Baikal. In: Advances in phycological studies. Sofia, Moscow: PENSOFT Publ. \& Univ. Publ. House. Pp. 73-89.

Krebs W.N., Bradbury J.P., Theriot E. 1987. Neogene and Quaternary Lacustrine Diatom Biochronology, Western USA. Palaios. 2: 505-513.

Usoltseva M., Likhacheva O., Pushkar V., Avramenko A. 2018. Alveolophora khursevichiae sp. nov. from the Miocene sediments of Khanka Lake (Far East). Nova Hedw. Beih. 147: $27-33$.

Wang Pinxian, Zhao Quanhong, Jian Zhimin, Cheng Xinrong, Huang Wei, Tian Jun, Wang Jiliang, Li Qianyu, Li Baohua, Su Xin. 2003. Thirty million year deep-sea records in the South China Sea. Chin. Sci. Bull. 48(23): 2524-2535.

Поступила 05.05.2019

Подписала в печать А.П. Ольштынская

\section{REFERENCES}

Dubrovina Y., Usoltseva M., Pushkar V., Likhacheva O. 2014. Tetracyclus chankaicus, a new species from Miocene sediments of the Khanka Lake, Primorye, Russia. Diatom Res. 29(2): 111-118. https://doi.org/10.1080/0269249X.2013.833137

Gladenkov Yu.B. 1991. Recent problem of zonal stratigraphy. Proc. Acad. Sci. USSR. Geol. Ser. 10: 3-8.

Iijuma A., Tada R. 1990. Evolution of Tertiary sedimentary basins of Japan in reference to opening of the Japan Sea. J. Fac. Sci. Hokkaido Univ. Ser. 2. 22(2): 121-171.

Khursevich G. 2006. In: Advances in phycological studies. Sofia, Moscow: PENSOFT Publ. \& Univ. Publ. House. Pp. 73-89.

Krebs W.N., Bradbury J.P., Theriot E. 1987. Neogene and Quaternary Lacustrine Diatom Biochronology, Western USA. Palaios. 2: 505-513.

Likhacheva O.Yu., Pushkar V.S., Cherepanova M.V., Pavlyutkin B.I. 2009. Zonal Diatom scale and general Neogene geobiological event of the Primorye. Bull. FEB RAS. 4: 64-72.

Meyen S.V. 1987. Introduction into Theory of Stratigraphy. Moscow: Nauka Press. 216 p. [Rus.] 
Moisseeva A.I. 1995. Differentiation of the continental Neogene deposits of the Far East under the Diatoms. Stratigraphy. Geol. correlation. 3(5): 92-103.

Pavlyutkin B.I., Chekryzhov I.Yu. 2007. The problem of the correlation far eastern Miocene floras of the climatic optimum epoch. Rep. Rus. Acad. Sci. 416(5): 662-665.

Pavlyutkin B.I., Golozubov V.V. 2010. Paleobotanical evidence of the time of the Sea of Japan origin. Bull. KRAUNTs. Earth Sci. 2(16): 19-26.

Pavlyutkin B.I., Petrenko T.I. 2010. Stratigraphy of Paleogene-Neogene deposits of the Primorye. Vladivostok: Dal'nauka Press. 164 p. [Rus.]

Pavlyutkin B.I., Ganzei S.S., Pushkar V.S., Petrenko T.I. 1993. Stratigraphy. Geol. correlation. 1(6): 40-47.

Pavlyutkin B.I., Pushkar V.S. Cherepanova M.V., Petrenko T.I. 2004. The problem of the Miocene stratigraphy of the Prikhankaisk depression (Russian Far East). Pacific Geol. 23(4): 73-85.

Pushkar V.S. 2012. In: Modern Paleontology: Proc. XV All-Rus. Micropaleontol. Meet. (Gelendzhik, Sept. 12-16, 2012). Moscow. Pp. 362-365. [Rus.]

Pushkar V.S., Korotky A.M. 1985. In: Cenozoic stratigraphy of the Far East. Vladivostok. Pp. 22-23. [Rus.]

Pushkar V.S., Cherepanova M.V., Likhacheva O.Yu. 2014. Detalization of the Pliocene Quaternary North Pacific Diatom Zonal Scale. Int. J. Algae. 16(3): 284-306. https://doi.org/10.1615/InterJAlgae.v16.i3.80

Resolution of the $4^{\text {th }}$ Interdepartmental Stratigraphic Meeting on Precambrian and the Phanerozoic of the South of the Far East and Eastern Transbaikalia. 1994. Khabarovsk. 124 p. [Rus.]

Tsoy I.B., Usoltseva M.V. 2016. Miocene freshwater diatoms from the deposits of the eastern slope of the underwater Ullin Plateau (Krishtofovich upland) of the Japan Sea. Stratigraphy. Geol. correlation. 24(3): 62-80. https://doi.org/10.7868/S0869592X16020071

Usoltseva M., Likhacheva O., Pushkar V., Avramenko A. 2018. Alveolophora khursevichiae sp. nov. from the Miocene sediments of Lake Khanka (Far East). Nova Hedw. Beih. 147: 27-33.

Wang Pinxian, Zhao Quanhong, Jian Zhimin, Cheng Xinrong, Huang Wei, Tian Jun, Wang Jiliang, Li Qianyu, Li Baohua, Su Xin. 2003. Thirty million year deep-sea records in the South China. Sea Chinese Sci. Bull. 48(23): 2524-2535.

Zhamoyda A.I. 2007. In: The questions of the Stratigraphy, Paleontology and Paleogeography. St. Petersburg: NIIZK SPbGU. Pp. 43-56. [Rus.] 
Algologia 2019, 29(2): 201-216

https://doi.org/10.15407/alg29.02.201

Pushkar V.S. ${ }^{1,2}$, Likhacheva O.Yu. ${ }^{1}$, Usoltseva M.V. ${ }^{3}$

${ }^{1}$ Far East Geological Institute FEB RAS,

159, 100 Let Vladivostok Ave., Vladivostok 690022, Russia

${ }^{2}$ Vladivostok State University Economic and Service,

41 Gogol Str., Vladivostok 690014, Russia

${ }^{3}$ Institute of Limnology SB RAS,

3 Ulan-Bator Str., Irkutsk 664033, Russia

ZONAL DIATOM SCALE OF THE CONTINENTAL NEOGENE IN PRIMORYE (MOST SOUTHERN TERRITORY OF THE RUSSIAN FAR EAST)

A significant stratigraphic and micropaleontological problem exists in the development of high-resolution biostratigraphic scales necessary when collecting basic data to construct a modern theory of Biospheric Stratigraphy and in determining the chronozone as a main operation unit. The chronozone should reflect general geobiological events which led to various conditions using the Paleobiosphere, which is a unique instrument used to mimic conditions of the ancient earth. The development and substantiation of zonal continental scales, which also include information on geobiological events, lag behind modern stratigraphy requirements The author's actual materials on the Far East Neogene diatom stratigraphic distribution allow us to decide this problem. The early Miocene is characterized by the intensive development of the Aulacoseira, Alveolophora, Ellerbeckia, Pseudoaulacosira, and Melosira genera. The global climate optimum has appeared between the early and middle Miocene. Many taxa of diatoms as well as the high species diversity of centric diatoms appeared and developed during the Middle-Late Miocene stage of diatom evolution. The Pliocene stage was marked by the appearance of the genera Stephanodiscus, Cyclotella, and Pliocaenicus. The greatest extinction of moderately warm-water species of centric births at the level of 3.6 million years corresponds to the growth and expansion of ice caps at both poles of the planet.

Ke y words: diatoms, Neogene, paleoclimate, stratigraphy, tectonic, the Far East 